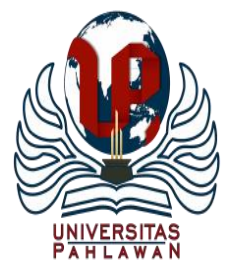

Edukatif : Jurnal Ilmu Pendidikan Volume 3 Nomor 2 Tahun 2021 Halm 321- 332

EDUKATIF: JURNAL ILMU PENDIDIKAN

Research \& Learning in Education

https:/ledukatif.org/index.php/edukatif/index

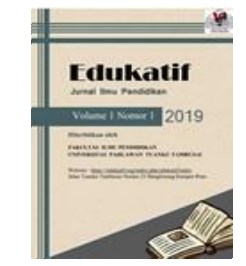

\title{
Penerapan Bimbingan Belajar Berbasis Prinsip - Prinsip Belajar dalam Islam Untuk Meningkatkan Etika Belajar Siswa
}

\author{
Rasimin $^{1 凶}{ }^{\otimes}$ Affan Yusra ${ }^{2}$, Hera Wahyuni ${ }^{3}$ \\ Universitas Jambi, Indonesia ${ }^{1,2,3}$ \\ E-mail : $\underline{\text { Rasimin.fkip@unja.ac.id }}^{1} \underline{\text { Affan15yusra@unja.ac.id }}^{2}, \underline{\text { herawahyuni@unja.ac.id }}^{3}$
}

\begin{abstract}
Abstrak
Dalam Islam untuk mendapatkan kejayaan belajar, etika harus dilibatkan saat proses interaksi antara belajar dan mengajar berlangsung. Dalam konteks belajar dan mengajar dalam perspektif Islam, etika yang dimaksud di sini adalah moral yang bersumber dari Alquran dan Sunnah. Ini adalah hal yang menarik untuk dipelajari. Karena mempelajari etika dalam Islam mengikuti tanda-tanda agama. Ilmu yang tidak bermanfaat bagi pemiliknya tidak hanya ditemukan pada siswa yang melakukan kecurangan akademik pada saat ujian berlangsung karena kurangnya etika dalam pembelajaran. Maka tujuan dari penelitian ini adalah bagaimana penerapan bimbingan belajar berdasarkan prinsip-prinsip belajar Islam dapat meningkatkan etika belajar di kalangan siswa. Sampel dalam penelitian ini menggunakan 34 siswa. Sampel dalam penelitian ini diambil dengan teknik purposive sampling berdasarkan kriteria dalam penelitian ini. Hasil penelitian setelah dilaksanakan pembelajaran tutor berdasarkan prinsip-prinsip pembelajaran Islam berjumlah dengan kategori hipotesis diterima. Mengingat pentingnya pembelajaran etika belajar bagi peserta didik, maka penting bagi konselor untuk menerapkan strategi bimbingan belajar berdasarkan prinsip-prinsip pembelajaran Islam dengan langkah-langkah untuk meningkatkan dan membentuk etika belajar pada peserta didik.
\end{abstract}

Kata Kunci: Prinsip Bimbingan Dalam Islam, Etika Belajar.

\begin{abstract}
In Islam, to achieve the success in learning, ethics must be involved when the process of interaction between the learning and teaching takes place. In the context of learning and teaching in an Islamic perspective, ethics is moral, sourced from the Qur'an and the Sunnah. This is an interesting thing to study. Because learning ethics in Islam follows religious signs. The knowledge that is not useful is not only found in students who cheat in the exam based on a lack of ethics in learning. So, the purpose of this study is to investigate how far the application of the learning based on the principles of Islam teachings increases the ethics of learning among students. The sample in this study were 34 students who was selected using purposive sampling technique based on the criteria in this study. The results after the implementation of learning based on the principles of Islam teachings amounted with the category of hypothesis accepted. Considering the importance of learning ethics for students, it is important for teachers to apply a learning strategy based on the principles of Islam teachings to improve and develop learning ethics in students.
\end{abstract}

Keywords: Principles of Tutoring in Islam, Learning Ethics.

Copyright (c) 2021 Rasimin, Affan Yusra, Hera Wahyuni

$\triangle$ Corresponding author

Email : Rasimin.fkip@unja.ac.id

DOI $:$ https://doi.org/10.31004/edukatif.v3i2.262

ISSN 2656-8063 (Media Cetak)

ISSN 2656-8071 (Media Online)

Edukatif : Jurnal Ilmu Pendidikan Vol 3 No 2 Tahun 2021 p-ISSN 2656-8063 e-ISSN 2656-8071 


\section{PENDAHULUAN}

Secara terminologi yang di ungkapkan oleh Kartanegara (Wiyono, 2016) dalam mengungkapkan etika belajar adalah filsafat moral atau ilmu akhlak, tidak lain daripada ilmu atau seni hidup (the art of living) yang mengajarkan bagaimana cara hidup bahagia, atau bagaimana memperoleh kebahagiaan. Hal ini terdapat dalam agama Islam untuk mendapat kemuliaan belajar, etika harus dilibatkan ketika proses interaksi antara yang belajar dan mengajar berlangsung . Dalam konteks belajar dan mengajar dalam perspektif Islam, etika yang dimaksud di sini adalah akhlak, bersumber dari Alquran dan 148 Sunnah. Ini menjadi hal menarik untuk dikaji. Karena etika belajar dalam Islam mengikuti rambu-rambu agama.

Tujuan etika belajar adalah untuk membentuk pribadi anak, supaya menjadi manusia yang baik, warga masyarakat, dan warga negara yang baik. Adapun kriteria manusia yang baik, warga masyarakat yang baik, dan warga negara yang baik bagi suatu masyarakat atau bangsa, secara umum adalah nilai-nilai sosial tertentu, yang banyak dipengaruhi oleh budaya masyarakat dan bangsanya (Mulyasana, 2019). Hal-hal apa saja yang mesti dianjurkan ataupun yang dilarang dalam dalam kondisi belajar? Bagaimana bersikap kepada guru dan materi yang dipelajari? Ini Merupakan bagian tidak bisa lepas dari etika belajar. Apalagi tujuan belajar dan mendapatkan ilmu, di dalamnya terkandung alasan teologis, yakni mengagungkan Allah.

Ilmu yang tidak bermanfaat bagi pemiliknya tidak hanya ditemukan pada siswa yang melakukan kecurangan akademik ketika ujian berlangsung yang didasarkan pada kurangnya etika dalam belajar seperti yang dijelaskan di atas. Namun juga dapat ditemui dalam kehidupan sehari-hari di kalangan para pelajar seperti: kurang mau beribadah, tidak menghargai dan menghormati orang yang lebih tua/ guru di sekolah, tidak toleran terhadap perbedaan baik segi agama maupun kebudayaan. Lembaga pendidikan, khususnya Sekolah Menengah Pertama (SMP) merupakan jembatan antara sekolah dasar dengan sekolah menengah atas, dalam tahap masa SMP berdasarkan tugas perkembangannya sudah dapat berfikir secara abstrak, menalar secara logis dan dapat menarik kesimpulan dari informasi yang tersedia dengan baik (Desmita, 2009).

Pada tahap ini siswa telah memasuki usia remaja, mereka mampu berfikir secara abstrak dan hipotesis. Pada usia ini siswa telah mampu memikirkan sesuatu yang akan atau mungkin terjadi, seperti membedakan mana yang baik dan mana yang buruk dalam kehidupannya. Sehingga siswa SMP dapat mengaplikasikan ilmu yang dimiliki dalam kehidupanya sendiri maupun masyarakat.

Berdasarkan studi pendahuluan melalui wawancara dengan guru mata pelajaran dan guru bimbingan dan konseling di MTsN 2 (MTsN Model) Kota Jambi diperoleh informasi bahwa masih terdapat siswa-siswi yang melakukan perbuatan yang menggambarkan kurangnya etika siswa dalam belajar seperti: kecurangan dalam ujian, siswa mencontek, bersikap cuek terhadap tugas yang diberikan guru, membolos pada jam pelajaran, malas belajar, sombong, tertidur pada saat jam pelajaran, asyik mengobrol dengan teman saat guru menjelaskan materi pelajaran dan menerima semua ilmu tanpa tau asal usul ilmu tersebut.

Siswa yang beretika dalam belajar dapat tergambar ciri-ciri yang melekat pada dirinya dan bagi orang lain ditandai dengan sikap seperti; taat beribadah, takut pada sang pencipta, mematuhi peraturan yang berlaku, sopan santun terhadap guru, orang tua, rajin dan bersungguh-sungguh mendalami suatu ilmu, kritis dan jujur dalam bertindak. Hal ini sejalan dengan yang di ungkapkan oleh Sutisna (Sutisna et al., 2020) mengungkapkan etika belajar yang terdiri dari: 1) menyucikan diri dari ahlak tercela, 2) mengurangi kesibukan duniawi, 3) patuh dan mendengarkan nasehat guru, 4) menghindari membanding-bandingkan guru, 5) tidak mengabaikan ilmu pengetahuan, 6) fokus pada suatu ilmu yang dipelajari, 7) memahami ilmu sesuai dengan tahapanya, 8) mengetahui penyebab gagalnya dalam belajar, 9) mengetahui tujuan pembelajaran, 10) mengetahui kaitan ilmu yang di pelajar. 
Dalam rangka membantu siswa untuk meningkatkan etika dalam belajar agar berguna bagi kehidupanya, bimbingan dan konseling merupakan suatu wadah yang memiliki peran membantu siswa-siswa agar dapat mengaplikasikan/mengamalkan ilmu yang telah mereka peroleh dari proses belajar agar dapat bermanfaat bagi kehidupanya sehari-hari. Novitasari dan Muhammad (Novitasari, 2017). Bimbingan dan konseling belajar merupakan bagian dari upaya guru bimbingan dan konseling untuk membantu dan memudahkan siswa dalam proses belajar (menuntut ilmu). Islam begitu menghargai seseorang yang mempermudah oranglain lain dalam suatu urusan yang baik (terlebih menuntut ilmu).

Di dalam bimbingan dan konseling terdapat ragam jenis bimbingan. Seperti yang dikemukakan oleh Winkel \& Hastuti (Winkel, 2013) bahwa ragam jenis bimbingan merujuk pada empat bidang utama yang ada dalam kehidupan meliputi: belajar, pribadi/sosial dan karir. Selain itu, bimbingan dan konseling memiliki beberapa jenis layanan untuk mengatasi permasalahan individu terutama dalam meningkatkan etika belajar, salah satunya adalah layanan penguasaan konten. Hal ini didasarkan hasil penelitian yang dilakukan oleh Fiah dan Adi (Fiah \& Purbaya, 2016) dalam hasil penelitiannya bahwa bimbingan belajar. Dengan menggunakan metode tersebut di atas dapat disimpulkan bahwa penerapan bimbingan belajar dalam meningkatkan hasil belajar peserta didik di SMP Negeri 12 Kota Bandar Lampung Tahun Pelajaran 2015/2016 adalah dengan menunjukkan cara-cara belajar yang efektif yaitu memberikan bimbingan teknis tentang belajar sehingga kesulitan belajar yang dialami dapat diselesaikan, membantu mempersiapkan diri dalam mengerjakan tugas dan ujian sehingga memiliki persiapan dalam menerima ujuan dan tugas-tugas yang diberikan, menunjukkan cara-cara menghadapi kesulitan dalam belajar.

Prayitno (Prayitno, 2017) Layanan penguasaan konten dapat membantu individu dalam menguasai konten tertentu cara untuk dapat meningkatkan etika belajar. Selama ini layanan penguasaan konten yang telah dilakukan dilapangan telah mengalami beberapa pengembangan namun belum bisa untuk meningkatkan etika belajar dikalangan siswa. Dalam layanan penguasan konten terdapat beberapa teknik dan pendekatan yang bisa digunakan dalam meningkatkan etika belajar individu, salah satunya dengan penerapan teknik bimbingan belajar berbasis prinsip-prinsip belajar dalam Islam.

Di dalam penelitian ini lebih dikhususkan pada bimbingan belajar yang dikaji dari sisi ilmu bimbingan dan konseling. Prayitno dan Erman (Prayitno ; Erman, 2013) mengemukakan bimbingan belajar merupakan suatu bidang bimbingan yang ditujukan untuk membantu siswa dalam mengenal, menumbuh dan mengembangkan diri, sikap kebiasaan belajar yang baik untuk menguasai pengetahuan dan keterampilan serta menyiapkannya melanjutkan pendidikan pada tingkat yang lebih tinggi. Abidin (Abidin, 2006) Kemudian Makna layanan bimbingan belajar (layanan pembelajaran) mengisyaratkan pada tujuan intinya, yaitu memberikan kemungkinan yang seluas-luasnya pada siswa untuk mengembangkan sikap dan kebiasaan belajar yang baik, keterampilan dan materi belajar yang sesuai dengan tingkat kecepatan,kesulitan belajar, potensi, dan perkembangan diri siswa.

(Yusra et al., 2017) Bimbingan belajar Berbasis prisip-prinsip belajar dalam Islam dapat diartikan sebagai suatu proses pemberian bantuan yang dilakukan oleh guru BK kepada siswa yang mengalami hambatan dalam belajar, membantu siswa menemukan metode belajar yang tepat, memilih program studi yang sesuainya diinginkanya melalui nilai-nila ajaran Islam yang dijadikan landasan berfikir atau landasan berpijak dan sumber motivasi agar proses belajar dapat berjalan dengan baik antara guru dan siswa. Bertolak dari latar belakang di atas dapat di peneliti tertarik untuk melakukan penelitian yang berjudul Penerapan Bimbingan belajar berbasis prisnip-prinsip belajar dalam Islam melalui layanan pengusaan konten untuk meningkatkan etika belajar pada siswa MTsN 2 (MTsN Model) Kota Jambi. 
DOI : https://doi.org/10.31004/edukatif.v3i2.262

\section{METODE PENELITIAN}

Metode yang digunakan dalam penelitian ini adalah penelitian tindakan kelas (class action research) menurut Basrowi "Penelitian Tindakan Kelas" merupakan penelitian praktis yang dilakukan untuk meningkatkan pembelajaran di kelas Basrowi dan Swandin (Yuliani, 2018). Penelitian ini menggunakan pendekatan deskriptif kualitatif. Tindakan kelas. Penelitian ini dilaksanakan dalam dua siklus melalui empat tahapan yaitu rencana tindakan, pelaksanaan, observasi, dan refleksi.

Pengumpulan data dilakukan dengan menggunakan soal tes, lembar observasi. Analisis data dapat dilakukan dengan cara sebagai berikut: (1) Mengelompokkan data dengan mengelompokkan, memilih, memfokuskan, dan menyederhanakan data menurut jenisnya dari awal pengumpulan data hingga penyusunan laporan; (2) Penyajian data yang dimiliki telah diseleksi dan akan disajikan dalam bentuk informasi sederhana. Informasi yang dimaksud merupakan gambaran proses pemberian arahan dan hasil yang diperoleh dari gabungan data observasi; (3) Kesimpulan. Berdasarkan pemaparan tersebut maka akan diperoleh kesimpulan data dalam bentuk kalimat yang singkat tetapi memiliki arti yang luas. Dari kesimpulan tersebut digunakan untuk menguji kebenaran dan mencocokkan makna data yang diperoleh di lapangan.

Hasil angket siswa mengenai hasil diperoleh dari nilai tes kognitif pada setiap akhir siklus. Untuk mengetahui peningkatan etika belajar siswa dilihat dari hasil observasi dan angket belajar etika siswa pada setiap siklus yang terdiri dari ketuntasan individual dan klasikal dengan tingkat ketuntasan $75 \%$ siswa menyatakan etika belajarnya meningkat. Dalam penelitian ini dilakukan 120 siswa kelas 8 MTsN 2 di Kota Jambi dan disaring kelayakannya melalui observasi dan angket; sebagai alat perekrutan. Peserta memiliki etika belajar yang rendah. Selain itu, mereka memiliki etika belajar yang baik yang tidak digunakan untuk penelitian.

Dalam penelitian ini menggunakan sampel satu kelas dengan jumlah siswa 40 orang yang mengambil sampel dengan teknik purposive sampling. Data dikumpulkan dan kemudian ditabulasi, yang kemudian dipisahkan. menjelaskan etika belajar yang harus dimiliki siswa meliputi; (1) menjauhkan diri dari sifat tercela; (2) serius dan bekerja keras dalam belajar; (3) siswa tidak boleh membual tentang pengetahuan mereka; (4) menghindari perdebatan; (5) biarkan siswa belajar secara bertahap; (6) siswa hendaknya tidak mempelajari ilmu lain sebelum menguasai ilmu yang dipelajari; (7) siswa hendaknya tidak mengikuti materi pelajaran yang tidak sesuai untuk diikuti; (8) siswa harus mempelajari cara untuk memperoleh pengetahuan yang berguna; (9) dalam belajar berusaha lebih dekat dengan Baik.

Kuisioner juga termasuk penilaian pengetahuan siswa tentang pembelajaran etika dalam islam. Peserta menjawab kuesioner tanpa intervensi dari luar pada awalnya dimana penanya diberikan setiap jawaban yang benar. Penilaian singkat kemudian dilakukan pada individu yang sama untuk mengevaluasi pengetahuan siswa tentang hal yang sama setelah diberikan bimbingan berdasarkan prinsip-prinsip pembelajaran dalam Islam. Padahal, setelah mengikuti bimbingan belajar berdasarkan prinsip-prinsip pembelajaran Islam, terlihat skor yang diberikan untuk setiap respon yang baik. bimbingan belajar berdasarkan prinsip-prinsip pembelajaran Islam yang dilakukan oleh pembimbing diberikan kepada seluruh peserta dalam satu kelas dan bertujuan untuk meningkatkan pengetahuan dan kesadaran siswa tentang apa yang mempengaruhi etika belajar dalam Islam.

Analisis statistik dilakukan dengan menggunakan Paket Statistik untuk Ilmu Sosial (SPSS) (versi21.0), IBM, New York, AS. Analisis deskriptif dilakukan untuk data demografi. Variabel kontinu dinyatakan sebagai mean \pm standar deviasi dan variabel kategori sebagai angka dan persentase. Uji t sampel berpasangan digunakan untuk membandingkan skor antara sebelum dan sesudah bimbingan berdasarkan prinsip-prinsip pembelajaran Islam. Hasil dianggap signifikan secara statistik untuk nilai $\mathrm{p}<0,05$. Untuk analisis multivariat, prinsip-prinsip pembelajaran Islam dilaksanakan sebagai variabel terikat, variabel bebas etika belajar. 
DOI : https://doi.org/10.31004/edukatif.v3i2.262

\section{HASIL DAN PEMBAHASAN}

Pada bagian ini akan di jelaskan hasil analisis angket yang telah disebar sebelum dan sesudah telah diberikan layanan bimbingan belajar berbasis prinsi-prinsip belajar dalam Islam. Deskripsi tingkat etika belajar pada siswa MTsN 2(MTsN Model) Kota Jambi. Berikut ini akan disajikan data awal tingkat etika belajar pada siswa MTsN 2(MTsN Model) Kota Jambi. yang menjadi kelompok eksperimen pada table 1 berikut ini:

Table 1 Tingkat Etika Belajar Pada Siswa MTsN 2(MTsN Model) Kota Jambi Sebelum diberikan layanan bimbingan belajar.

\begin{tabular}{|c|c|c|c|c|c|c|c|}
\hline \multirow[b]{2}{*}{ Variabel } & \multirow[b]{2}{*}{ Indikator } & \multirow{2}{*}{$\begin{array}{l}\text { Frekuensi } \\
\quad \%\end{array}$} & \multicolumn{5}{|c|}{ Skor } \\
\hline & & & Tinggi & $\begin{array}{c}\text { Sedan } \\
\mathrm{g}\end{array}$ & Kurang & $\begin{array}{c}\text { Renda } \\
h\end{array}$ & Total \\
\hline \multirow{9}{*}{$\begin{array}{l}\text { Etika } \\
\text { belajar }\end{array}$} & $\begin{array}{l}\text { Menjauhkan diri dari sifat } \\
\text { tercela }\end{array}$ & $\begin{array}{l}\text { Frekuensi } \\
\%\end{array}$ & $\begin{array}{c}3 \\
8,83\end{array}$ & $\begin{array}{c}26 \\
76,47\end{array}$ & $\begin{array}{c}5 \\
14,70\end{array}$ & 0 & $\begin{array}{c}34 \\
100\end{array}$ \\
\hline & $\begin{array}{l}\text { Bersungguh-sungguh dan } \\
\text { berkerjakeras }\end{array}$ & $\begin{array}{l}\text { Frekuensi } \\
\%\end{array}$ & $\begin{array}{c}20 \\
58,82\end{array}$ & $\begin{array}{c}14 \\
41,18\end{array}$ & 0 & 0 & $\begin{array}{c}34 \\
100\end{array}$ \\
\hline & $\begin{array}{l}\text { Hendaknya siswa tidak } \\
\text { menyombongkan diri dengan } \\
\text { ilmu yang dimilikinya }\end{array}$ & $\begin{array}{l}\text { Frekuensi } \\
\%\end{array}$ & $\begin{array}{c}13 \\
38,24\end{array}$ & $\begin{array}{c}20 \\
58,82\end{array}$ & $\begin{array}{c}1 \\
2,94\end{array}$ & 0 & $\begin{array}{c}34 \\
100\end{array}$ \\
\hline & $\begin{array}{l}\text { Hendaklah menghindari } \\
\text { berdebat }\end{array}$ & $\begin{array}{l}\text { Frekuensi } \\
\%\end{array}$ & $\begin{array}{c}4 \\
11,76\end{array}$ & $\begin{array}{c}23 \\
67,65\end{array}$ & $\begin{array}{c}7 \\
20,59\end{array}$ & 0 & $\begin{array}{c}34 \\
100\end{array}$ \\
\hline & $\begin{array}{l}\text { Hendaklah siswa belajar secara } \\
\text { bertahap }\end{array}$ & $\begin{array}{l}\text { Frekuensi } \\
\%\end{array}$ & $\begin{array}{c}8 \\
23,53\end{array}$ & $\begin{array}{c}24 \\
70,59\end{array}$ & $\begin{array}{c}2 \\
5,88\end{array}$ & 0 & $\begin{array}{c}34 \\
100\end{array}$ \\
\hline & $\begin{array}{l}\text { Hendaknya siswa jangan } \\
\text { mempelajari ilmu yang lain } \\
\text { sebelum ia menguasai ilmu } \\
\text { yang di pelajarinya }\end{array}$ & $\begin{array}{c}\text { Frekuensi } \\
\%\end{array}$ & 0 & $\begin{array}{c}27 \\
79,41\end{array}$ & $\begin{array}{c}7 \\
20,59\end{array}$ & 0 & $\begin{array}{c}34 \\
100\end{array}$ \\
\hline & $\begin{array}{l}\text { Hendaknya siswa tidak } \\
\text { mengikuti pokok bahasan yang } \\
\text { belum pantas di ikutinya }\end{array}$ & $\begin{array}{l}\text { Frekuensi } \\
\%\end{array}$ & 0 & $\begin{array}{c}29 \\
85,29\end{array}$ & $\begin{array}{c}5 \\
14,71\end{array}$ & 0 & $\begin{array}{c}34 \\
100\end{array}$ \\
\hline & $\begin{array}{l}\text { Hendaknya siswa mempelajari } \\
\text { cara-cara mendapatkkan ilmu } \\
\text { yang bermanfaat }\end{array}$ & $\begin{array}{l}\text { Frekuensi } \\
\%\end{array}$ & $\begin{array}{c}16 \\
47,06\end{array}$ & $\begin{array}{c}18 \\
52,94\end{array}$ & 0 & 0 & $\begin{array}{c}34 \\
100\end{array}$ \\
\hline & $\begin{array}{l}\text { Hendaknya dalam belajar } \\
\text { berupaya mendekatkan diri } \\
\text { kepada Allah }\end{array}$ & $\begin{array}{l}\text { Frekuensi } \\
\%\end{array}$ & $\begin{array}{c}34 \\
100\end{array}$ & 0 & 0 & 0 & $\begin{array}{c}34 \\
100\end{array}$ \\
\hline & Keseluruhan & $\begin{array}{l}\text { Frekuensi } \\
\%\end{array}$ & $\begin{array}{c}98 \\
32,03\end{array}$ & $\begin{array}{c}181 \\
59,15\end{array}$ & $\begin{array}{c}27 \\
8,82\end{array}$ & 0 & $\begin{array}{l}306 \\
100\end{array}$ \\
\hline
\end{tabular}

Berdasarkan table 1 dapat dilihat etika belajar pada siswa MTsN 2(MTsN Model) Kota Jambi pada keseluruhan indikator terdapat 181 siswa yang berada pada kategori sedang dengan frekuensi 58,15\% , 98 orang siswa yang berada pada kategori tinggi dengan frekuensi 32,03\%, 27 siswa yang berada pada kategori kurang dengan frekuensi $8,82 \%$, dan nol atau nihil yang berada pada kategori rendah

Dari hasil analisis deskriptif diperoleh hasil masih terdapat siswa dengan etika belajar pada siswa MTsN 2(MTsN Model) Kota Jambi yang termasuk dalam kategori sedang, dilihat dari berbagai aspek berikut ini: 
1. Menjauhkan diri dari sifat tercela

Pada siswa MTsN 2(MTsN Model) Kota Jambi pada aspek ini terdapat 3 siswa yang berada pada kategori tinggi dengan frekuensi 8,83\%, 26 siswa yang berada dalam kategori sedang dengan frekuensi 76,47\%, 5 siswa yang berada pada kategori kurang dengan frekuensi $14,70 \%$, dan nol atau nihil siswa yang berada dalam kategori rendah.

2. Bersungguh-sungguh dan berkerjakeras

Pada siswa MTsN 2(MTsN Model) Kota Jambi pada aspek ini terdapat 20 siswa yang berada pada kategori tinggi dengan frekuensi 58,82\%, 14 siswa yang berada dalam kategori sedang dengan frekuensi 41,18\%, dan nol atau nihil siswa yang berada dalam kategori kurang dan rendah.

3. Hendaknya siswa tidak menyombongkan diri dengan ilmu yang dimilikinya

Pada siswa MTsN 2(MTsN Model) Kota Jambi pada aspek ini terdapat 13 siswa yang berada pada kategori tinggi dengan frekuensi 38,24\%, 20 siswa yang berada dalam kategori sedang dengan frekuensi 58,82\%, 1 siswa yang berada pada kategori kurang dengan frekuensi $2,94 \%$, dan nol atau nihil siswa yang berada dalam kategori rendah.

4. Hendaklah menghindari berdebat

Pada siswa MTsN 2(MTsN Model) Kota Jambi pada aspek ini terdapat 4 siswa yang berada pada kategori tinggi dengan frekuensi 11,76\%, 23 siswa yang berada dalam kategori sedang dengan frekuensi 67,65\%, 7 siswa yang berada pada kategori kurang dengan frekuensi20,59\%, dan nol atau nihil siswa yang berada dalam kategori rendah.

5. Hendaklah siswa belajar secara bertahap

Pada siswa MTsN 2(MTsN Model) Kota Jambi pada aspek ini terdapat 8 siswa yang berada pada kategori tinggi dengan frekuensi 23,53\%, 24 siswa yang berada dalam kategori sedang dengan frekuensi 70,59\%, 2 siswa yang berada pada kategori kurang dengan frekuensi 5,88\%, dan nol atau nihil siswa yang berada dalam kategori rendah.

6. Hendaknya siswa jangan mempelajari ilmu yang lain sebelum ia menguasai ilmu yang di pelajarinya

Pada siswa MTsN 2(MTsN Model) Kota Jambi pada aspek ini terdapat 27 siswa yang berada pada kategori sedang dengan frekuensi 79,41\%, 7 siswa yang berada dalam kategori kurang dengan frekuensi 20,59\%, dan nol atau nihil siswa yang berada dalam kategori tinggi dan rendah.

7. Hendaknya siswa tidak mengikuti pokok bahasan yang belum pantas di ikutinya

Pada siswa MTsN 2(MTsN Model) Kota Jambi pada aspek ini terdapat 29 siswa yang berada pada kategori sedang dengan frekuensi 85,29\%, 5 siswa yang berada dalam kategori kurang dengan frekuensi 14,71\%, dan nol atau nihil siswa yang berada dalam kategori tinggi dan rendah.

8. Hendaknya siswa mempelajari cara-cara mendapatkkan ilmu yang bermanfaat

Pada siswa MTsN 2(MTsN Model) Kota Jambi pada aspek ini terdapat 16 siswa yang berada pada kategori tinggi dengan frekuensi 47,06\%, 18 siswa yang berada dalam kategori sedang dengan frekuensi 52,94\%, dan nol atau nihil siswa yang berada dalam kategori kurang dan rendah.

9. Hendaknya dalam belajar berupaya mendekatkan diri kepada Allah 
327 Penerapan Bimbingan Belajar Berbasis Prinsip - Prinsip Belajar dalam Islam Untuk Meningkatkan Etika Belajar Siswa - Rasimin, Affan Yusra, Hera Wahyuni

DOI : https://doi.org/10.31004/edukatif.v3i2.262

Pada siswa MTsN 2(MTsN Model) Kota Jambi pada aspek ini terdapat 34 siswa yang berada pada kategori tinggi dengan frekuensi $100 \%$ dan nol atau nihil siswa yang berada dalam kategori sedang, kurang dan rendah

Table 2 Tingkat Etika Belajar Pada Siswa MTsN 2(MTsN Model) Kota Jambi Sesudah diberikan layanan bimbingan belajar.

\begin{tabular}{|c|c|c|c|c|c|c|c|}
\hline \multirow{2}{*}{$\begin{array}{l}\text { Variab } \\
\text { el }\end{array}$} & \multirow{2}{*}{ Indikator } & \multirow{2}{*}{$\begin{array}{l}\text { Frekuensi } \\
\quad \%\end{array}$} & \multicolumn{5}{|c|}{ Skor } \\
\hline & & & Tinggi & Sedang & Kurang & Rendah & Total \\
\hline \multirow{9}{*}{$\begin{array}{l}\text { Etika } \\
\text { belajar }\end{array}$} & $\begin{array}{l}\text { Menjauhkan diri dari sifat } \\
\text { tercela }\end{array}$ & $\begin{array}{c}\text { Frekuensi } \\
\%\end{array}$ & $\begin{array}{c}3 \\
8,83\end{array}$ & $\begin{array}{c}27 \\
79,41\end{array}$ & $\begin{array}{c}4 \\
11,77\end{array}$ & 0 & $\begin{array}{c}34 \\
100\end{array}$ \\
\hline & $\begin{array}{l}\text { Bersungguh-sungguh dan } \\
\text { berkerjakeras }\end{array}$ & $\begin{array}{c}\text { Frekuensi } \\
\%\end{array}$ & $\begin{array}{c}13 \\
38,24 \\
\end{array}$ & $\begin{array}{c}19 \\
55,88\end{array}$ & $\begin{array}{c}2 \\
5,88 \\
\end{array}$ & 0 & $\begin{array}{c}34 \\
100\end{array}$ \\
\hline & $\begin{array}{l}\text { Hendaknya siswa tidak } \\
\text { menyombongkan diri dengan } \\
\text { ilmu yang dimilikinya }\end{array}$ & $\begin{array}{c}\text { Frekuensi } \\
\%\end{array}$ & $\begin{array}{c}11 \\
32,36\end{array}$ & $\begin{array}{c}22 \\
64,70\end{array}$ & $\begin{array}{c}1 \\
2,94\end{array}$ & 0 & $\begin{array}{c}34 \\
100\end{array}$ \\
\hline & $\begin{array}{l}\text { Hendaklah menghindari } \\
\text { berdebat }\end{array}$ & $\begin{array}{l}\text { Frekuensi } \\
\%\end{array}$ & $\begin{array}{c}12 \\
35,29\end{array}$ & $\begin{array}{c}22 \\
64,71\end{array}$ & 0 & 0 & $\begin{array}{c}34 \\
100\end{array}$ \\
\hline & $\begin{array}{l}\text { Hendaklah siswa belajar secara } \\
\text { bertahap }\end{array}$ & $\begin{array}{c}\text { Frekuensi } \\
\%\end{array}$ & $\begin{array}{c}8 \\
23,53\end{array}$ & $\begin{array}{c}23 \\
67,65\end{array}$ & $\begin{array}{c}3 \\
8,82\end{array}$ & 0 & $\begin{array}{c}34 \\
100\end{array}$ \\
\hline & $\begin{array}{l}\text { Hendaknya siswa jangan } \\
\text { mempelajari ilmu yang lain } \\
\text { sebelum ia menguasai ilmu } \\
\text { yang di pelajarinya }\end{array}$ & $\begin{array}{c}\text { Frekuensi } \\
\%\end{array}$ & 0 & $\begin{array}{c}23 \\
67,65\end{array}$ & $\begin{array}{c}11 \\
32,35\end{array}$ & 0 & $\begin{array}{c}34 \\
100\end{array}$ \\
\hline & $\begin{array}{l}\text { Hendaknya siswa tidak } \\
\text { mengikuti pokok bahasan yang } \\
\text { belum pantas di ikutinya }\end{array}$ & $\begin{array}{c}\text { Frekuensi } \\
\%\end{array}$ & $\begin{array}{c}5 \\
14,71\end{array}$ & $\begin{array}{c}29 \\
85,29\end{array}$ & 0 & 0 & $\begin{array}{c}34 \\
100\end{array}$ \\
\hline & $\begin{array}{l}\text { Hendaknya siswa mempelajari } \\
\text { cara-cara mendapatkkan ilmu } \\
\text { yang bermanfaat }\end{array}$ & $\begin{array}{c}\text { Frekuensi } \\
\%\end{array}$ & $\begin{array}{c}18 \\
52,94\end{array}$ & $\begin{array}{c}16 \\
47,06\end{array}$ & 0 & 0 & $\begin{array}{c}34 \\
100\end{array}$ \\
\hline & $\begin{array}{l}\text { Hendaknya dalam belajar } \\
\text { berupaya mendekatkan diri } \\
\text { kepada A } \\
\text { Llah }\end{array}$ & $\begin{array}{c}\text { Frekuensi } \\
\%\end{array}$ & $\begin{array}{c}34 \\
100\end{array}$ & 0 & 0 & 0 & $\begin{array}{c}34 \\
100\end{array}$ \\
\hline \multicolumn{2}{|r|}{ Keseluruhan } & $\begin{array}{c}\text { Frekuensi } \\
\%\end{array}$ & $\begin{array}{c}104 \\
33,99\end{array}$ & $\begin{array}{c}158 \\
51,63\end{array}$ & $\begin{array}{c}21 \\
6,86\end{array}$ & 0 & $\begin{array}{l}306 \\
100\end{array}$ \\
\hline
\end{tabular}

Berdasarkan table 2 dapat dilihat etika belajar pada siswa MTsN 2(MTsN Model) Kota Jambi dari hasil analisis deskriptif diperoleh hasil sudah terdapat siswa dengan etika belajar pada siswa MTsN 2(MTsN Model) Kota Jambi yang termasuk dalam kategori sedang, dilihat dari berbagai aspek berikut ini:

1. Menjauhkan diri dari sifat tercela

Pada siswa MTsN 2(MTsN Model) Kota Jambi pada aspek ini terdapat 3 siswa yang berada pada kategori tinggi dengan frekuensi 8,83\%, 27 siswa yang berada dalam kategori sedang dengan frekuensi 79,41\%, 4 siswa yang berada pada kategori kurang dengan frekuensi $11,77 \%$, dan nol atau nihil siswa yang berada dalam kategori rendah. 
328 Penerapan Bimbingan Belajar Berbasis Prinsip - Prinsip Belajar dalam Islam Untuk Meningkatkan Etika Belajar Siswa - Rasimin, Affan Yusra, Hera Wahyuni

DOI : https://doi.org/10.31004/edukatif.v3i2.262

2. Bersungguh-sungguh dan berkerjakeras

Pada siswa MTsN 2(MTsN Model) Kota Jambi pada aspek ini terdapat 13 siswa yang berada pada kategori tinggi dengan frekuensi 38,24\%, 19 siswa yang berada dalam kategori sedang dengan frekuensi 55,88\%, 2 siswa yang berada pada kategori kurang dengan frekuensi 5,88, dan nol atau nihil siswa yang berada dalam kategori rendah.

3. Hendaknya siswa tidak menyombongkan diri dengan ilmu yang dimilikinya

Pada siswa MTsN 2(MTsN Model) Kota Jambi pada aspek ini terdapat 11 siswa yang berada pada kategori tinggi dengan frekuensi 32,36\%, 22 siswa yang berada dalam kategori sedang dengan frekuensi 64,70\%, 1 siswa yang berada pada kategori kurang dengan frekuensi2,94\%, dan nol atau nihil siswa yang berada dalam kategori rendah.

4. Hendaklah menghindari berdebat

Pada siswa MTsN 2(MTsN Model) Kota Jambi pada aspek ini terdapat12

35,29siswa yang berada pada kategori tinggi dengan frekuensi 35,29\% siswa 22 siswa yang berada dalam kategori sedang dengan frekuensi 64,70\%, dan nol atau nihil siswa yang berada dalam kategori kurang dan rendah.

5. Hendaklah siswa belajar secara bertahap

Pada siswa MTsN 2(MTsN Model) Kota Jambi pada aspek ini terdapat 8 siswa yang berada pada kategori tinggi dengan frekuensi 23,53\%, 23 siswa yang berada dalam kategori sedang dengan frekuensi 67,65\%, 3 siswa yang berada pada kategori kurang dengan frekuensi8,82\%, dan nol atau nihil siswa yang berada dalam kategori rendah.

6. Hendaknya siswa jangan mempelajari ilmu yang lain sebelum ia menguasai ilmu yang di pelajarinya

Pada siswa MTsN 2(MTsN Model) Kota Jambi pada aspek ini terdapat 23 siswa yang berada pada kategori sedang dengan frekuensi 67,65\%, 11 siswa yang berada dalam kategori kurang 32,35\%, dan nol atau nihil siswa yang berada dalam kategori tinggi dan rendah.

7. Hendaknya siswa tidak mengikuti pokok bahasan yang belum pantas di ikutinya

Pada siswa MTsN 2(MTsN Model) Kota Jambi pada aspek ini terdapat 5 siswa yang berada pada kategori tinggi dengan frekuensi 14,71\%,29 siswa yang berada pada kategori sedang dengan frekuensi 85,2\%, dan nol atau nihil siswa yang berada dalam kategori kurang dan rendah.

8. Hendaknya siswa mempelajari cara-cara mendapatkkan ilmu yang bermanfaat

Pada siswa MTsN 2(MTsN Model) Kota Jambi pada aspek ini terdapat 18 siswa yang berada pada kategori tinggi dengan frekuensi 52,94\%, 16 siswa yang berada dalam kategori sedang 47,06\%, dan nol atau nihil siswa yang berada dalam kategori kurang dan rendah.

9. Hendaknya dalam belajar berupaya mendekatkan diri kepada Allah

Pada siswa MTsN 2(MTsN Model) Kota Jambi pada aspek ini terdapat 34 siswa yang berada pada kategori tinggi dengan frekuensi $100 \%$ dan nol atau nihil siswa yang berada dalam kategori sedang, kurang dan rendah. 
Berdasarkan hasil pre-test dan post-test yang telah dilakukan di MTs N 2 Kota Jambi terlihat adanya perubahan atau meningkatnya etika belajar siswa MTs N 2 Kota Jambi setalah diberikan perlakuan bimbingan belajar berbasis prinsip-prinsip belajar dalam Islam melalui layanan penguasaan konten. Sebagaian permasalahan dalam penelitian ini adalah rendahnya etika belajar siswa MTsN 2 (MTsN Model) Kota Jambi. Berdasarkan hal tersebut karena guru belum menggunakan teknik atau pendekatan tertentu sehingga masih terdapat siswa yang memiliki etika belajar yang rendah. Perlu pemilihan teknik atau pendekatan tertentu yang tepat untuk memecahkan masalah tersebut. Bimbingan belajar yang dimaksud adalah yang berbasis prinsip-prinsip belajar dalam islam melalui layanan penguasaan konten. Mahmudi (Mahmudi, 2016) dalam proses memberikan makna bimbingan dan konseling Islam" suatu proses dalam bimbingan yang dilaksanakan berdasarkan ajaran Islam, untuk membantu individu yang bermasalah dan untuk mencapai kebahagian dunia dan akhirat. Penelitian tindakan layanan ini terdiri dari dua siklus dimana masing-masing setiap siklusnya terdapat dua kali pemberian layanan. Pada siklus 1 pertemuan 1 dengan tema mengenal diri sendiri dengan melakukan bimbingan belajar yang terdiri dari 34 siswa, sedangkan pada siklus 1 pertemuan 2 dengan tema hakikat belajar dengan bimbingan belajar yang terdiri dari 34 siswa. Pada siklus 2 pertemuan 1 dengan tema manfaat berfikir kritis dalam belajar dengan melakukan bimbingan belajar yang terdiri dari 34 siswa, sedangkan pada siklus 2 pertemuan 2 dengan tema pentingnya memiliki sifat jujur dalam ujian dengan melakukan bimbingan belajar yang terdiri dari 34 siswa.

Hasil pengamatan menunjukkan bahwa bimbingan belajar berbasis prinsip-prinsip belajar dalam islam ternyata memberikan dampak pada etika belajar siswa MTsN 2 (MTsN Model) Kota Jambi. Berdasarkan dari variabel etika belajar yang pada setiap indikatornya:

1. Menjauhkan diri dari sifat tercela pada katerogori tinggi terdapat 3 siswa berada pada kategori tinggi dengan persentase $8,83 \%$, pada kategori sedang terdapat 26 siswa dengan persentase $76,47 \%$, dan kategori kurang terdiri dari 5 siswa dengan persentase 14,70\%, sedangkan pada siklus kedua pada indikator ini dalam kategori tinggi terdapat 3 siswa dengan persentase $8,83 \%$, pada kategori sedang terdapat 27 siswa dengan persentase $79,41 \%$, dan pada kategori kurang terdapat 4 siswa dengan persentase $11,77 \%$. Dapat disimpulkan bahwa terjadi peningkatan tetapi tidak terlalu signifikan.

2. Bersungguh-sungguh dan bekerja keras pada katerogori tinggi terdapat 20 siswa berada pada kategori tinggi dengan persentase $58,82 \%$, pada kategori sedang terdapat 14 siswa dengan persentase $41,18 \%$, sedangkan pada siklus kedua pada indikator ini dalam kategori tinggi terdapat 13 siswa dengan persentase $38,24 \%$, pada kategori sedang terdapat 19 siswa dengan persentase $55,88 \%$, dan pada kategori kurang terdapat 2 siswa dengan persentase 5,88\%. Dapat disimpulkan bahwa terjadi peningkatan tetapi tidak terlalu signifikan.

3. Hendaknya siswa tidak menyombongkan diri dengan ilmu yang dimilikinya pada katerogori tinggi terdapat 13 siswa berada pada kategori tinggi dengan persentase 38,24\%, pada kategori sedang terdapat 20 siswa dengan persentase 58,82\%, dan kategori kurang terdiri dari 1 siswa dengan persentase 2,94\%, sedangkan pada siklus kedua pada indikator ini dalam kategori tinggi terdapat 11 siswa dengan persentase 32,36\%, pada kategori sedang terdapat 22 siswa dengan persentase $64,70 \%$, dan pada kategori kurang terdapat 1 siswa dengan persentase 2,94\%. Dapat disimpulkan bahwa terjadi peningkatan tetapi tidak terlalu signifikan.

4. Hendaknya menghindari berdebat pada katerogori tinggi terdapat 4 siswa berada pada kategori tinggi dengan persentase $11,76 \%$, pada kategori sedang terdapat 23 siswa dengan persentase $67,65 \%$, dan kategori kurang terdiri dari 7 siswa dengan persentase 20,59\%, sedangkan pada siklus kedua pada indikator ini dalam kategori tinggi terdapat 7 siswa dengan persentase 20,59\%, pada kategori sedang 
terdapat 22 siswa dengan persentase $64.70 \%$, dan pada kategori kurang terdapat 5 siswa dengan persentase $14,71 \%$. Dapat disimpulkan bahwa terjadi peningkatan tetapi tidak terlalu signifikan.

5. Hendaknya siswa belajar secara bertahap pada katerogori tinggi terdapat 8 siswa berada pada kategori tinggi dengan persentase $23,53 \%$, pada kategori sedang terdapat 24 siswa dengan persentase $70,59 \%$, dan kategori kurang terdiri dari 2 siswa dengan persentase 5,88\%, sedangkan pada siklus kedua pada indikator ini dalam kategori tinggi terdapat 8 siswa dengan persentase 23,53\%, pada kategori sedang terdapat 23 siswa dengan persentase $67,65 \%$, dan pada kategori kurang terdapat 3 siswa dengan persentase $8,82 \%$. Dapat disimpulkan bahwa terjadi penurunan tetapi tidak terlalu signifikan.

6. Hendaknya siswa jangan mempelajari ilmu yang lain sebelum ia menguasai ilmu yang dipelajarinya pada kategori sedang terdapat 27 siswa dengan persentase 79,41\%, dan kategori kurang terdiri dari 7 siswa dengan persentase $20,59 \%$, sedangkan pada siklus kedua pada kategori sedang terdapat 23 siswa dengan persentase $67,65 \%$, dan pada kategori kurang terdapat 11 siswa dengan persentase $32,35 \%$. Dapat disimpulkan bahwa terjadi peningkatan tetapi tidak terlalu signifikan.

7. Hendaknya siswa tidak mengikuti pokok bahasan yang belum pantas di ikutinya pada kategori sedang terdapat 29 siswa dengan persentase $85,29 \%$, dan kategori kurang terdiri dari 5 siswa dengan persentase $14,71 \%$, sedangkan pada kategori sedang terdapat 29 siswa dengan persentase $85,29 \%$, dan pada kategori kurang terdapat 5 siswa dengan persentase $14,71 \%$. Dapat disimpulkan bahwa tidak terjadi penurunan ataupun peningkatan pada indikator ini.

8. Hendaknya siswa mempelajari cara-cara mendapatkan ilmu yang bermanfat pada katerogori tinggi terdapat 16 siswa berada pada kategori tinggi dengan persentase 47,06\%, pada kategori sedang terdapat 18 siswa dengan persentase 52,94\%, sedangkan pada siklus kedua pada indikator ini dalam kategori tinggi terdapat 18 siswa dengan persentase 52,94\%, pada kategori sedang terdapat 19 siswa dengan persentase $47,06 \%$, Dapat disimpulkan bahwa terjadi peningkatan tetapi tidak terlalu signifikan.

9. Hendaknya dalam belajar berupaya mendekatkan diri kepada Allah pada katerogori tinggi terdapat 34 siswa berada pada kategori tinggi dengan persentase $100 \%$, sedangkan pada siklus kedua pada indikator ini dalam kategori tinggi terdapat 34 siswa dengan persentase 100\%. Dapat disimpulkan bahwa tidak mengalami penaikan ataupun penurunan

Dari penjabaran diatas dapat dilihat bahwa bimbingan belajar berbasis prinsip-prinsip belajar dalam islam dapat meningkatkan etika belajar siswa, hal ini dibuktikan dari 9 indikator etika belajar terdapat 6 indikator yang mengalami penaikan signifikan yaitu indikator menjauhkan diri dari sifat tercela, bersungguhsungguh dan berkerja keras, hendaknya siswa tidak menyombongkan diri dengan ilmu yang dimilikinya, hendaknya menghindari berdebat, hendaknya siswa jangan mempelajari ilmu yang lain sebelum ia menguasai ilmu yang dipelajarinya, dan hendaknya siswa mempelajari cara-cara mendapatkan ilmu yang bermanfaat. Sedangkan 1 indikator lainnya tidak mengalami perubahan antara pree-test dan post-test yakni indikator hendaknya siswa tidak mengikuti pokok bahasan yang belum pantas diikutinya, serta pada 2 indikator hendaknya siswa belajar secara bertahap dan hendaknya dalam belajar berupaya mendekatkan diri kepada Allah dimana pada indikator ini tidak mengalami penurunan ataupun peningkatan pada pree-test dan posttest.

Dengan demikian hipotesis yang menyatakan model bimbingan belajar berbasis prinsip-prinsip belajar dalam islam dapat meningkatkan etika belajar siswa kelas VIII B MTsN 2 (MTs Model) Kota Jambi dapat dibuktikan. Bimbingan belajar tidak hanya digunakan dalam meningkatkan etika belajar siswa namu sejalan dengan yang dilakukan oleh Sriyono (Sriyono, 2016) dengan diadakannya bimbingan belajar dapat meningkatkan kemandirian belajar hal ini juga termasuk salah satu dari etika belajar. kan pada keesaan Allah. 
331 Penerapan Bimbingan Belajar Berbasis Prinsip - Prinsip Belajar dalam Islam Untuk Meningkatkan Etika Belajar Siswa - Rasimin, Affan Yusra, Hera Wahyuni

DOI : https://doi.org/10.31004/edukatif.v3i2.262

Hal ini sejalan juga dengan hasil penelitian yang dilakukan oleh (Fadhilah, 2016) Prinsip ketauhidan inilai yang membedakan pandangan pendidikan Islam dengan teori Behavioristik. Karena teori aliran barat lebih mengedepankan rasionalisme dan tidak mengkaitkannya dengan nilai-nilai keagamaan.

\section{KESIMPULAN}

Hasil observasi pelaksanaan pada siklus I berada pada kategori baik sedangkan observasi pelaksanaan siklus II berada pada kategori sangat baik. Penerapan bimbingan belajar berdasarkan prinsip-prinsip pembelajaran Islam dapat mengingatkan siswa pada pembelajaran etis, hal ini terlihat dari peningkatan siklus observasi prestasi belajar siswa I dan siklus II. Pembinaan berdasarkan prinsip-prinsip pembelajaran Islam melalui layanan penguasaan konten telah dilaksanakan dengan baik antara lain kelengkapan media perangkat bimbingan dan penyusunan rencana bimbingan sebelum pemberian layanan, dalam setiap pemberian materi bimbingan pembelajaran berdasarkan hasil pelaksanaan bimbingan belajar berbasis pembelajaran Prinsipprinsip dalam Islam dapat disimpulkan bahwa penggunaan bimbingan belajar berdasarkan prinsip-prinsip pembelajaran dalam Islam dapat meningkatkan etika belajar siswa.

\section{SARAN}

Pada pelaksanaan bimbingan belajar berbasis prinsip-prinsip belajar dalam islam hendaknya guru BK memberikan kebebasan dan keluasan kepada siswa untuk mengembangkan kreatifitas dan keterampilan dalam membantu siswa meningkatkan etika belajarnya. Sebaiknya bagi siswa dalam mengikuti proses bimbingan belajar berbasis prinsip-prinsip belajar dalam islam hendaknya mempraktekkan ilmu yang telah dipelajarinya dapat di praktekkan sesuai dengan etikanya.

\section{DAFTAR PUSTAKA}

Abidin, Z. (2006). Layanan Bimbingan Belajar sebagai Upaya Peningkatan Kualitas Proses Belajar Mengajar. Pemikiran Alternatif Kependidikan, 11(1), 1-12.

Desmita. (2009). Perkembangan peserta didik. REMAJA ROSDAKARYA.

Fadhilah, N. (2016). MODEL BIMBINGAN BELAJAR. Hikmatuna, 2, 235-260.

Fiah, R. El, \& Purbaya, A. P. (2016). Penerapan Bimbingan Belajar dalam Meningkatkan Hasil Belajar Peserta Didik di SMP Negeri 12 Kota Bandar Lampung Tahun Pelajaran 2015/2016 Rifda El Fiah, Adi Putra Purbaya. 03(2), 171-184.

Mahmudi, I. (2016). PEMBENTUKAN KARAKTER MELALUI LAYANAN BIMBINGAN DAN KONSELING ISLAMI. Jurnal Bimbingan Dan Konseling, 3.

Mulyasana, D. (2019). Konsep Etika Belajar dalam Pemikiran Pendidikan Islam Klasik. 26(1).

Novitasari, Y.;Muhammad N. (2017). BIMBINGAN DAN KONSELING BELAJAR (AKADEMIK) DALAM PERSPEKTIF ISLAM. Indonesia Journal or Education Counseling, 1, 53-78.

Prayitno ; Erman. (2013). Dasar-Dasar BIMBINGAN dan KONSELING (3rd ed.). Rineka Cipta.

Prayitno. (2017). KONSELING PROFESIONAL YANG BERHASIL (Layanan dan Kegiatan Pendukung) (1st ed.). RajaGrafindo Persada.

Sriyono, H. (2016). PROGRAM BIMBINGAN BELAJAR UNTUK MEMBANTU MENINGKATKAN KEMANDIRIAN BELAJAR SISWA. 8(2), 118-131.

Sutisna, U., Studi, P., \& Informatika, T. (2020). Etika belajar dalam islam. 7(1), 49-58. 
332 Penerapan Bimbingan Belajar Berbasis Prinsip - Prinsip Belajar dalam Islam Untuk Meningkatkan Etika Belajar Siswa - Rasimin, Affan Yusra, Hera Wahyuni

DOI : https://doi.org/10.31004/edukatif.v3i2.262

Winkel, W. . \& S. H. (2013). BIMBINGAN DAN KONSELING DI INSTITUSI PENDIDIKAN (9th ed.). media abadi.

Wiyono, A. H. (2016). ETIKA BELAJAR DALAM AL-QUR'AN (Kajian Tafsir Maudhu'i). Al-Hikmah, $4(2), 75-86$.

Yuliani, W. (2018). METODE PENELITIAN DESKRIPTIF KUALITATIF DALAM PERSPEKTIF BIMBINGAN DAN KONSELING. 2(2), 83-91. https://doi.org/10.22460/q.v1i1p1-10.497

Yusra, A., Yuwono, D., Sugiharto, P., \& Sutoyo, A. (2017). Jurnal Bimbingan Konseling Model Bimbingan Belajar Berbasis Prinsip-prinsip Belajar dalam Islam untuk Meningkatkan Kemanfaatan Ilmu Abstrak. 6(2), 106-112. 